\title{
First Description of a Male Shompen Frog, Limnonectes shompenorum Das 1996, with Notes on Distribution
}

\author{
S.R. Chandramouli
}

Department of Ecology and Environmental Sciences, School of Life Sciences, Pondicherry University, Puducherry-605014, India (findthesnakeman@gmail.com)

$T_{s}^{\mathrm{h}}$ he anuran family Dicroglossidae Anderson 1871 is represented in the Nicobar Archipelago by two species in two genera (Das 1999), the Nicobar Wart Frog (Minervarya nicobariensis) and the Shompen Frog (Limnonectes shompenorum). The latter was described by Das (1996) based on four adult females with males unknown. Das (1996) speculated that males could be larger than the females he encountered. More recently, Harikriahnan and Vaudevan (2018) stated that they did not encounter any calling males. Herein I describe a topotypical adult male L. shompenorum from Great Nicobar. Measurements follow Chandramouli and Prasad (2018).

A topotypical male Limnonectes shompenorum (Fig. 1) collected from Campbell Bay $\left(7.018^{\circ} \mathrm{N}, 93.923^{\circ} \mathrm{E}\right.$; elev. $12 \mathrm{~m}$ asl), Great Nicobar (DOSMB05001) had a SVL $=53.24 \mathrm{~mm}$. The head is relatively short (HL:SVL 0.37 ) and the trunk stout (AG:SVL 0.3); head nearly as long as broad (HL:HW 1.02) with a blunt, rounded snout; nostril situated closer to the snout tip than to the eyes (EN:ES 0.62); canthal and supra-tympanic folds evident, with a faint black interior margin; tympanum smaller than the eye (TYH:ED 0.33); eyes relatively large (ED:HL 0.31); interorbital distance $(3.84 \mathrm{~mm}$ ) narrower than internarial distance $(4.97 \mathrm{~mm})$; loreal region concave. Upper arms short (UAL:SVL 0.2); lower arms as long as upper arms (LAL:SVL 0.2); palms longer (PAL:LAL 1.24); relative length of fingers III $>\mathrm{I}>\mathrm{IV}>\mathrm{II}$; fingertips with swollen discs; dorsal surface of the first finger with a thick, white nuptial pad. Thighs
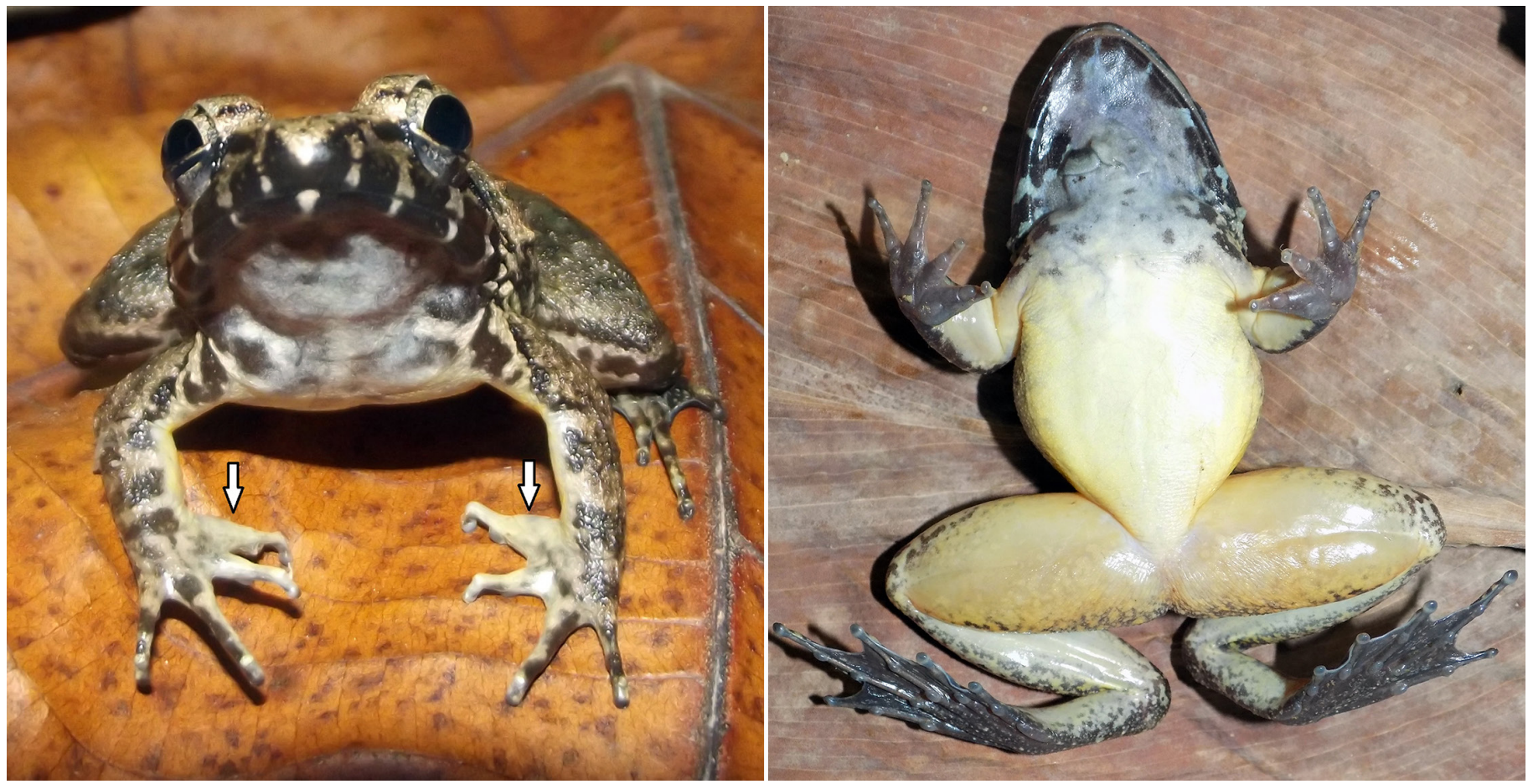

Fig. 1. Dorsal (left) and ventral (right) views of a live typotypical male Schompen Frog (L. shompenorum). Arrows indicate the nuptial pads; note also the dark gular region, which is unpatterned in females. Photographs by the author. 
long, about half as long as the body (FEL:SVL 0.51); tibia longer (FEL:SVL 0.57) than the femur (FEL:TBL 0.9); feet as long as the femur (FEL:FOL 1.0); toes long with bulbous discs at the tips; relative toe lengths $\mathrm{IV}>\mathrm{III}>\mathrm{V}>\mathrm{II}>\mathrm{I}$; webbing between toes complete, extending to the discs on all toes; inner metatarsal tubercle vertically elongated, outer metatarsal tubercle absent. Overall dorsal coloration greyish brown without any discernible pattern; thighs with feeble dark transverse bands; upper and lower lips with three dark spots; gular region distinctly darker than the venter with large, indistinct dark spots (note that females have unpatterned throats). Das (1996) noted that males of this species generate a loud barking call.

During this study, I recorded L. shompenorum at Campbell Bay $\left(7.0218^{\circ} \mathrm{N}, 93.921^{\circ} \mathrm{E}\right.$; elev. $70 \mathrm{~m}$ asl), Govind Nagar $\left(7.00220^{\circ} \mathrm{N}, 93.88108^{\circ} \mathrm{E}\right.$; elev. $102 \mathrm{~m}$ asl), Shastri Nagar $\left(6.809^{\circ} \mathrm{N}, 93.884^{\circ} \mathrm{E}\right.$; elev. $79 \mathrm{~m}$ asl), Galathea $\left(6.823^{\circ} \mathrm{N}\right.$, $93.865^{\circ} \mathrm{E}$; elev. $44 \mathrm{~m}$ asl.), Navy Dera $\left(7.135^{\circ} \mathrm{N}, 93.883^{\circ} \mathrm{E}\right.$; elev. $0 \mathrm{~m}$ asl), and Afra Bay $\left(7.186^{\circ} \mathrm{N}, 93.735^{\circ} \mathrm{E}\right.$; elev. $67 \mathrm{~m}$ asl) on Great Nicobar and at Pulo Ulon on Little Nicobar. This species also has been reported from the adjacent Sundaic
Island of Sumatra (Inger and Iskander 2005; Teynie et al. 2010).

\section{Literature Cited}

Chandramouli, S.R. and K.V.D. Prasad. 2018. Taxonomic status of the endemic Andaman Bullfrog Kaloula baleata ghoshi Cherchi, 1954 (Anura: Microhylidae) with notes on distribution and natural history. Tropical Natural History 18: 40-53.

Das, I. 1996. Limnonectes shompenorum, a new species of ranid frog of the Rana macrodon complex from Great Nicobar, India. Journal of South Asian Natural History 2: 127-134.

Das, I. 1999. Biogeography of the amphibians and reptiles of the Andaman and Nicobar Islands, India, pp. 43-77. In: H. Ota (ed.), Tropical Island Herpetofauna: Origin, Current Diversity, and Conservation. Proceedings of the International Symposium, "Diversity of Reptiles, Amphibians, and Other Terrestrial Animals on Tropical Islands - Origin, Current Status, and Conservation, " held at the University of the Ryukyus, Okinawa, Japan, from 6 to 7 June 1998. Elsevier Science BV, Amsterdam, The Netherlands.

Harikrishnan, S. and K. Vasudevan. 2018. Amphibians of the Andaman \& Nicobar Islands: distribution, natural history, and notes on taxonomy. Alytes 36: 238265.

Inger, R.F. and D.T. Iskandar. 2005. A collection of amphibians from West Sumatra, with description of a new species of Megophrys (Amphibia: Anura). Raffles Bulletin of Zoology 53: 133-142.

Teynié, A., P. David, and A. Ohler. 2010. Note on a collection of amphibians and reptiles from western Sumatra (Indonesia), with the description of a new species of the genus Bufo. Zootaxa 2416: 1-43. 